\title{
Abbreviations of Frequently Cited Texts
}

B Badiou: A Subject to Truth (Peter Hallward)

BE Being and Event (Alain Badiou)

C1 Cinema 1: The Movement-Image (Gilles Deleuze)

C2 Cinema 2: The Time-Image (Gilles Deleuze)

$\mathrm{C}$ Conditions (Alain Badiou)

CD 'Cinema as a Democratic Emblem' (Alain Badiou)

D Deleuze: The Clamor of Being (Alain Badiou)

DF 'Dialectiques de la fable' (Alain Badiou)

E Ethics: An Essay on the Understanding of Evil (Alain Badiou)

FF Film Fables (Jacques Rancière)

HI Handbook of Inaesthetics (Alain Badiou)

IT Infinite Thought: Truth and the Return of Philosophy (Alain Badiou)

LW Logics of Worlds: Being and Event, 2 (Alain Badiou)

M Metapolitics (Alain Badiou)

MP Manifesto for Philosophy (Alain Badiou)

MS The Meaning of Sarkozy (Alain Badiou)

NN Number and Numbers (Alain Badiou)

OB On Beckett (Alain Badiou)

$\mathrm{P} \quad$ Polemics (Alain Badiou)

PA The Politics of Aesthetics (Jacques Rancière)

SM Second manifeste pour la philosophie (Alain Badiou)

SP Saint Paul: The Foundation of Universalism (Alain Badiou)

S20 The Seminar of Jacques Lacan, Book XX (Jacques Lacan)

TC The Century (Alain Badiou)

TO Briefings on Existence (Alain Badiou)

TW Theoretical Writings (Alain Badiou)

WC1 What is Cinema?: Volume 1 (André Bazin)

WC2 What is Cinema?: Volume 2 (André Bazin) 
